\title{
Comparing growth and physiological responses of Globba schomburgkii Hook. f. and Globba marantina L. under hydroponic and soil conditions
}

\author{
Piyamart Phantong1, Thitiporn Machikowa ${ }^{2}$, Piyaporn Saensouk ${ }^{3}$, Nooduan Muangsan ${ }^{1 *}$ \\ ${ }^{1}$ School of Biology, Institute of Science, Suranaree University of Technology, Nakhon Ratchasima, 30000, Thailand, \\ ${ }^{*}$ E mail: HYPERLINK "mailto:nooduan@sut.ac.th" nooduan@sut.ac.th ${ }^{2}$ School of Crop Production Technology, Institute of Agricultural \\ Technology, Suranaree University of Technology, Nakhon Ratchasima, 30000, Thailand, ${ }^{3}$ Department of Biology, Faculty of Science, \\ Mahasarakham University, Khamriang, Kantarawichai, 41150, Thailand
}

\section{A B S TR A C T}

Globba (Zingiberaceae) are attractive herbaceous plants widely used as ornamental plants. However, cultivation is limited because of low propagation rate and depends on the season only. This research aimed to compare growth and physiological responses of Globba schomburgkii Hook. f. and Globba marantina L. under both soil and hydroponic conditions. In vitro plantlets (8 cm in height) were transplanted to a hydroponic culture with the nutrient film technique (NFT). In soil culture, the plantlets were transplanted to small pots containing sand: burned rice husk: peat moss (1:1:1 by volume). Vegetative growth characteristics were measured at 15, 30, 45 and 60 days after transplanting (DAT), whereas reproductive growth and physiological characteristics were measured at 60 DAT. All there was $100 \%$ survival in both growth conditions. Plants of both species grown in hydroponic conditions had higher shoot length, leaf area and stem diameter, except number of shoots than when propagated in soil conditions. Moreover, both species grown in hydroponics had earlier inflorescences and more flowers, indicating that they can be flowering out of season. Additionally, in hydroponic conditions both species had significant higher stomatal conductivity, whereas there were no significant differences in photosynthetic rates, transpiration rates and leaf temperature when compared with soil conditions. Therefore, our study provides evidence that G. schomburgkii and G. marantina are capable of adapting to hydroponic conditions and that hydroponics may be a suitable method for propagating Globba and other ginger plant species into cut flower or potted plants all year round.

Keywords: Hydroponics, Nutrient film technique (NFT), Soilless culture, Stomatal conductivity, Zingiberaceae

\section{INTRODUCTION}

The genus Globba is a perennial herb and it's an ornamental of Zingiberaceae family in Thailand with high economic value due to demand for its attractive inflorescence. It is not traded widespread because the commercial varieties have little variation. The conventional propagation of the genus Globba uses underground rhizomes, fruits and bulbils (Pimmuen et al., 2014). In addition propagation of this genus seasonally depends.

Hydroponic systems have been suggested as an alternative method for cultivating plants. In recent years, hydroponic systems have became popular in agricultural activities. Hydroponic systems are soilless. The roots are immersed in water or a nutrient solution thus allowing simple control of the nutrient solution by adjusting the concentration of the hydroponic nutrient solution (Libia et al., 2012; Toshiki, 2012). Hydroponic devices have been developed for larger scale commercial use and have been successfully applied for both cut flowers and vegetables. Many crops have been successfully produced by this method including plants such as Anthurium andreanum (Dufour and Guérin, 2005), Alpine strawberry (Fragaria vesca L.) (Caruso et al., 2011), Daucus carota L. (Asaduzzaman et al., 2013), Cucumis melo L. cv. Panna (Asao et al., 2013) and Leafy lettuce (Selma et al., 2012). The high yield nutrient film technique (NFT) system can be used for cut flower production and for propagation of many plant species (Monnet et al., 2002; Nosir, 2011). In this system, the plant roots are constantly bathed in thin film solution separate that by thin plastic film which allows the plants to get sufficient oxygen and nutrients (Libia et al., 2012). There are many nutrient formulas of hydroponics and the $\mathrm{pH}$ of solution should range from 5.5 to 6.5 (Libia

\footnotetext{
${ }^{*}$ Corresponding author:

Aricléia de Moraes Catarino, Post-Graduation Program in Agriculture in the Humid Tropics, National Research Institute of the Amazon, Manaus, AM, Brazil. E-mail: amoraescatarino@gmail.com
} 
et al., 2012; Toshiki, 2012). In order to satisfy the increasing demand for plant material, hydroponic culture has potential to produce plant material year-round under controlled growth conditions. At present, there are few researches about hydroponics on plants of the family Zingiberaceae.

We were interested in investigating the growth of the plant in family Zingiberaceae using a hydroponic system to find the possibility of a new way to support and production the genus Globba species and other related plants to cut flowers economically in the near future. We hypothesized that both $G$. schomburgkii and G. marantina grow faster and would start early flowering in hydroponic culture than in soil culture. The main objective of this study was to compare the growth and physiological characters of two Globba species between soil and hydroponic conditions. So we compared growth parameters of the surviving plantlets, number of shoots, height of shoots, stem diameter, number of leaves, length of leaves and reproductive parameters, and physiological parameters of photosynthetic rate, transpiration rate, and stomatal conductivity between G. schomburgkii and G. marantina grown in a soil condition and in a hydroponic condition. We predict that hydroponic grown plants will have growth rate greater parameters.

\section{MATERIALS AND METHODS}

\section{Plant materials and preparation}

Two Globba species were used in the experiments including $G$. schomburgkii and $G$. marantina for multiple shoot proliferation. The microshoots of two Globba species were cultured for 60 days on Murashige and Skoog (MS) (Murashige and Skoog, 1962) medium supplemented with $3 \%(\mathrm{w} / \mathrm{v})$ sucrose, $3 \mathrm{mg} / \mathrm{L}$ Benzyladenine $(\mathrm{BA})$ and $0.7 \%(\mathrm{w} / \mathrm{v})$ agar adjusting the $\mathrm{pH}$ to 5.7-5.8 (Pimmuen et al., 2014). Cultures were maintained at $25 \pm 2{ }^{\circ} \mathrm{C}$, $16 \mathrm{~h}$ photoperiod at the tissue culture laboratory of the equipment building F2 at Suranaree University of Technology.

\section{Acclimatization}

After culturing for 2 months in vitro plantlets were then moved outside tissue culture room for a 3 weeks acclimatization period. The in vitro plantlets of about $8 \mathrm{~cm}$ with 3-4 leaves and which had both roots and shoots were thoroughly washed with tap water to remove residual agar from roots and then transplanted to a hydroponic system using the nutrient film technique (NFT) and to small pots containing sand: burned rice husk: peat moss $(1: 1: 1$ by volume). The plants were maintained under greenhouse conditions with the evaporative cooling system and closing of roof window of the experimental research at Suranaree University of Technology farm (SUT farm).

\section{Nutrient solution}

SUT nutrient solution (Damna et. al., 2017) was applied to the G. schomburgkii and G. marantina in hydroponic and soil conditions. The nutrient solution contains the following amounts of $\mathrm{Ca}\left(\mathrm{NO}_{3}\right)_{2} 4 \mathrm{H}_{2} \mathrm{O} 2.2 \mathrm{~kg} / 10 \mathrm{~L}, \mathrm{Fe}-$ EDTA $(12 \% \mathrm{Fe}) 0.08 \mathrm{~kg} / 10 \mathrm{~L}, \mathrm{KNO}_{3} 1.18 \mathrm{~kg} / 10 \mathrm{~L}$, $\mathrm{MgSO}_{4} 1.18 \mathrm{~kg} / 10 \mathrm{~L}, \mathrm{KH}_{2} \mathrm{PO}_{4} 0.53 \mathrm{~kg} / 10 \mathrm{~L}, \mathrm{Fe}-\mathrm{EDDHA}$ $(6 \% \mathrm{Fe}) 0.004 \mathrm{~kg} / 10 \mathrm{~L}$ and Nicsprey $0.05 \mathrm{~kg} / 10 \mathrm{~L}$.

\section{Hydroponic conditions}

The plantlets were transplanted to the NFT hydroponic system $(50 \times 150 \times 50 \mathrm{~cm})$ during September -November 2016 and grown in small plastic cups $(4 \times 4.5 \mathrm{~cm}$.) containing perlites for 60 days. All experiments had three replicates. Each plant was irrigated with SUT nutrient solution at electrical conductivity (EC) of nutrient solution between 1.6- $2.4 \mathrm{mS} / \mathrm{cm}$ and $\mathrm{pH}$ was maintained at 5.5-6.5. The EC and $\mathrm{pH}$ of the nutrient solution were checked daily with manual digital conductivity and $\mathrm{pH}$ meters. The plants were maintained under greenhouse conditions by closing the roof windows at the SUT farm.

\section{Soil conditions}

The in vitro plantlets were transplanted to small pots $(14 \times 12 \mathrm{~cm})$ containing sand: burned rice husk: peat moss (1:1:1 by volume) and then covered with polythene wrap and watered on every alternate day to maintain humidity. All the experiments had three replicates and kept at greenhouse conditions with the closing of roof window at SUT farm. Each plant was irrigated with $200 \mathrm{ml}$ of the same nutrients solution as used in hydroponics once daily in the morning. The transplantation dates for soil conditions were identical to the experimental dates for the hydroponic system.

\section{Measurements \\ Growth parameters}

Final measurements were collected on November 2016. The percentage of the surviving plantlets, number of shoots, shoot heights, stem diameter, number of leaves and length of leaves were recorded every 15 days after transplanting (DAT) until the completion of the study. In this study, the height of plants was measured from the base up to the shoot tip. The leaves at the first, second and third from the shoot tip were selected as a representative leaf length measurement because lower leaves often withered. Leaf length was measured along the axis of the midrib to the base and the width was measured at right-angles to left-angles of the axis, at the point of the greatest width of each leaf. The height, length and width were recorded in centimeter $(\mathrm{cm})$. Reproductive growth parameters including the number of inflorescences, length of inflorescences and number of flowers were determined at 60 DAT. Inflorescence length was measured at the first inflorescence of the shoot tip and recorded in centimeter $(\mathrm{cm})$. 


\section{Physiological parameters}

Physiological parameters including photosynthetic rate, transpiration rate, and stomatal conductivity were measured with LCi-SD portable photosynthesis (ADC Bio Scientific Ltd., Country) at 60 DAT. Data collection occurred between 9 and 12 AM on windless and sunny days as described by Syros et al. (2004). To measure the photosynthetic rate, the second and third leaves (fully expanded and healthy) from five plants were selected through stratified standard sampling from both conditions. The first leaf was avoided because it was newly emergent and would not be representative of the plant.

\section{Statistical analysis}

This study used a completely randomized design (CRD) to research. The mean values were compared for each variable by applying generalized linear models, using number of days as an independent and number of shoots, the height of shoots, stem diameter, number of leaves, length of leaves, number of inflorescence, inflorescence length and number of flowers as response variables. We tested each variable for normality and homoscedasticity. All models were validated using standardized residuals. To test for physiological difference between plants grown in soil and hydroponic condition, we conducted T-tests. We determined if significant differences between soil and hydroponic conditions as well as the number of days existed with a two way ANOVA. We then performed a post-hoc Duncan's multiple range test (DMRT) to identify specific group differences. All tests were considered significant at $\mathrm{P}=0.05$ and analyses were done using the SPSS package version 16. We reported all descriptive statistics as means \pm standard error.

\section{RESULTS}

\section{Growth responses of $G$. schomburgkii and $G$. marantina}

All plantlets survived until termination of the experiment. Results of all data are presented in Table 1. G. schomburgkii plants grown in both conditions had growth rate increases with increasing number of days. We detected significant differences between soil and hydroponic conditions as well as the number of days with ANOVA. For G. schomburgkii at 60 DAT, shoot length $(20.42 \pm 0.27 \mathrm{~cm}, P<0.05$; Table 1$)$, leaf area $\left(5.91 \pm 0.10 \mathrm{~cm}^{2}, P<0.05\right.$; Table 1) and stem diameter $(0.46 \pm 0.00 \mathrm{~cm}, P<0.05$; Table 1$)$ were significantly higher in hydroponic culture. However, number of shoots (16.00 $\pm 0.31 \mathrm{~cm}, P<0.05$; Table 1) was significantly lower in hydroponic culture and number of leaves was not significantly different. In addition, it was also observed that plants grown in hydroponics had earlier inflorescent emergence than those grown in soil (32 DAT in comparison to $34 \mathrm{DAT})$. They had more inflorescences, longer inflorescences and more flowers than in soil conditions (Fig. 1A, C; Table 3). In hydroponics, G. schomburgkii bulbils had long white papaya seed-like appearance and new plantlets regenerated from bulbils (Fig. 1E).

Plantlets survived in both growth conditions with $100 \%$ survival rate. For G. marantina at $60 \mathrm{DAT}$, a number of shoots (7.63 $\pm 0.43, P<0.05$; Table 1$)$ was lower in hydroponics, However, shoot length $(16.06 \pm 0.15 \mathrm{~cm}, P<0.05$; Table 1$)$, leaf area $\left(4.93 \pm 0.05 \mathrm{~cm}^{2}, P<0.05\right.$; Table 1$)$, stem diameter $(0.46 \pm 0.01 \mathrm{~cm}, P<0.05$; Table 1$)$ were significantly higher in hydroponics and a number of leaves $(3.72 \pm 0.09, P \square$ 0.05; Table 1) was no significant difference. In addition, plants grown in hydroponics had earlier inflorescences than those grown in soil (34 DAT in comparison to 36 DAT). They had fewer inflorescences and shorter inflorescences than in soil conditions (Fig. 1B, D), however hydroponic plants had more flowers (Table 3). Similarly, bulbils of $G$. marantina regenerated into new plantlets (Fig. 1F).
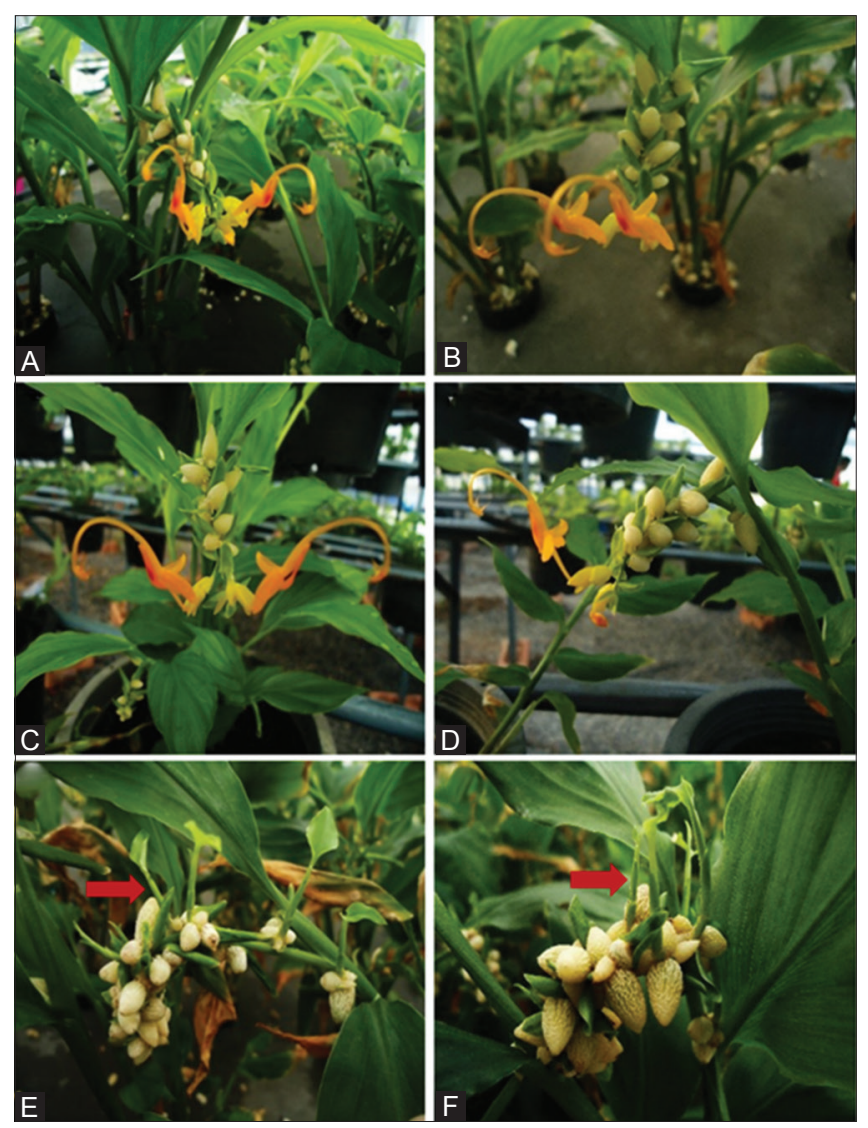

Fig 1. Growth characteristics; (A) The inflorescence of G. schomburgkii grown in hydroponic condition at 38 DAT, (B) The inflorescence of G. marantina grown in hydroponic condition at 41 DAT, (C) The inflorescence of G. schomburgkii grown in soil condition at 41 DAT, (D) The inflorescence of $\mathrm{G}$. marantina grown in soil condition at 47 DAT, (E) New plantlets regenerated from bulbils of $G$. schomburgkii grown in hydroponic condition (red arrow) and ( $F$ ) New plantlets regenerated from bulbils of $\mathrm{G}$. marantina grown in hydroponic condition (red arrow). 
We performed linear regression with days and condition as predictors for number of shoots, shoot length, number of leaves, leaf area and stem diameter. We found that days was a strongly significant predictor for all response variables except number of leaves in the hydroponic G. schombergii treatment (Fig. 2) and G. marantina (Fig. 3). In general, biweekly most growth measurements indicated a consistently higher growth pattern for hydroponics compared to soil conditions.

Furthermore, it was observed that the roots of plants grown in soil conditions were short and large, tuberous roots. While, the plant roots grown in hydroponics were longer and had more branched, fibrous roots, than those grown in soil conditions (Fig. 4).

\section{Physiological responses of G. schomburgkii and G. marantina}

In both species, there were no significant differences in the physiological responses except for stomatal conductivity between soil and hydroponic cultures (Table 2). Plants grown in the hydroponic conditions had higher stomatal conductivity, $0.22 \mu \mathrm{mol} \mathrm{CO} \mathrm{CO}_{2} / \mathrm{mol}^{-}$for $G$. schomburgkii and $0.11 \mu \mathrm{mol} \mathrm{CO} / 2 / \mathrm{mol}^{-}$for $G$. marantina when compared with soil conditions.

\section{DISCUSSIONS}

\section{Growth responses in hydroponic and soil conditions}

This is the first report on the ornamental plants of ginger family plants grown in hydroponic conditions. Two months

Table 1: Growth indices of G. schomburgkii and G. marantina.

\begin{tabular}{|c|c|c|c|c|c|}
\hline \multirow[t]{2}{*}{ Parameters } & \multirow[t]{2}{*}{ Treatments } & \multicolumn{4}{|c|}{ DAT } \\
\hline & & 15 & 30 & 45 & 60 \\
\hline \multirow[t]{4}{*}{ No. of shoots \pm SE } & T1 & $4.60 \pm 0.20^{\mathrm{a}}$ & $6.93 \pm 0.32^{b}$ & $12.77 \pm 0.42^{a}$ & $16.00 \pm 0.31^{\mathrm{a}}$ \\
\hline & T2 & $4.80 \pm 0.15^{\mathrm{a}}$ & $8.03 \pm 0.44^{\mathrm{a}}$ & $13.83 \pm 0.69^{a}$ & $14.33 \pm 0.73^{a}$ \\
\hline & T3 & $1.43 \pm 0.15^{c}$ & $3.97 \pm 0.18^{c}$ & $8.77 \pm 0.34^{b}$ & $11.07 \pm 0.82^{b}$ \\
\hline & $\mathrm{T} 4$ & $1.93 \pm 0.09^{b}$ & $3.87 \pm 0.15^{c}$ & $6.20 \pm 0.23^{c}$ & $7.63 \pm 0.43^{c}$ \\
\hline$F$-test & & ** & ** & $\star *$ & ** \\
\hline \multirow[t]{4}{*}{ Shoot length \pm SE } & $\mathrm{T} 1$ & $6.77 \pm 0.29^{d}$ & $8.88 \pm 0.20^{c}$ & $11.10 \pm 0.35^{c}$ & $11.17 \pm 0.50^{\circ}$ \\
\hline & T2 & $8.48 \pm 0.49^{c}$ & $8.62 \pm 0.15^{c}$ & $8.98 \pm 0.25^{d}$ & $9.22 \pm 0.08^{d}$ \\
\hline & T3 & $11.89 \pm 0.16^{a}$ & $14.04 \pm 0.56^{a}$ & $17.93 \pm 0.68^{a}$ & $20.42 \pm 0.27^{a}$ \\
\hline & $\mathrm{T} 4$ & $10.35 \pm 0.34^{b}$ & $12.41 \pm 0.20^{b}$ & $15.68 \pm 0.30^{b}$ & $16.06 \pm 0.15^{b}$ \\
\hline$F$ - test & & ** & ** & ** & ** \\
\hline \multirow[t]{4}{*}{ No. of leaves \pm SE } & $\mathrm{T} 1$ & $3.66 \pm 0.13$ & $3.86 \pm 0.08$ & $3.89 \pm 0.08$ & $4.01 \pm 0.03$ \\
\hline & T2 & $3.78 \pm 0.09$ & $3.78 \pm 0.14$ & $3.78 \pm 0.08$ & $3.84 \pm 0.08$ \\
\hline & T3 & $3.40 \pm 0.09$ & $3.52 \pm 0.04$ & $3.68 \pm 0.12$ & $3.80 \pm 0.04$ \\
\hline & $\mathrm{T} 4$ & $3.68 \pm 0.13$ & $3.68 \pm 0.06$ & $3.69 \pm 0.09$ & $3.72 \pm 0.09$ \\
\hline$F$ - test & & ns & ns & ns & ns \\
\hline \multirow[t]{4}{*}{ Leaf area \pm SE } & $\mathrm{T} 1$ & $2.48 \pm 0.23 b$ & $3.54 \pm 0.12$ & $4.57 \pm 0.13 b c$ & $4.83 \pm 0.08 b$ \\
\hline & T2 & $3.24 \pm 0.13 a$ & $4.05 \pm 0.10$ & $4.12 \pm 0.18 c$ & $4.27 \pm 0.14 \mathrm{c}$ \\
\hline & T3 & $2.40 \pm 0.05 b$ & $4.16 \pm 0.33$ & $5.45 \pm 0.06 a$ & $5.91 \pm 0.10 a$ \\
\hline & $\mathrm{T} 4$ & $2.70 \pm 0.05 b$ & $3.77 \pm 0.12$ & $4.92 \pm 0.21 b$ & $4.93 \pm 0.05 b$ \\
\hline$F$ - test & & ** & ns & ** & ** \\
\hline \multirow[t]{4}{*}{ Stem diameter \pm SE } & $\mathrm{T} 1$ & $0.26 \pm 0.01$ & $0.38 \pm 0.01 b$ & $0.38 \pm 0.01 \mathrm{c}$ & $0.39 \pm 0.00 b$ \\
\hline & T2 & $0.25 \pm 0.02$ & $0.26 \pm 0.01 \mathrm{c}$ & $0.33 \pm 0.00 d$ & $0.39 \pm 0.01 b$ \\
\hline & T3 & $0.30 \pm 0.00$ & $0.45 \pm 0.02 a$ & $0.45 \pm 0.00 a$ & $0.46 \pm 0.00 a$ \\
\hline & $\mathrm{T} 4$ & $0.25 \pm 0.02$ & $0.34 \pm 0.01 b$ & $0.43 \pm 0.01 b$ & $0.46 \pm 0.01 a$ \\
\hline$F$ - test & & ns & ** & ** & $\star \star$ \\
\hline
\end{tabular}

Means in the same column followed by different letters a-d are significantly different according to the Duncan's multiple range test (DMRT) at $P \leq 0.05$. a, b, c, and d denotes difference between groups soil and hydroponic. T1: G. schomburgkii grown in soil condition, T2: G. marantina grown in soil condition, T3: G. schomburgkii grown in hydroponic condition, T4: G. marantina grown in hydroponic condition. $\left({ }^{* \star}\right.$ indicates significant P-value at 0.01 level; ns $=$ not significant)

Table 2: Physiological indices of G. schomburgkii and G. marantina grown in soil and hydroponic conditions at 60 DAT

\begin{tabular}{|c|c|c|c|c|c|}
\hline Species & Conditions & $\begin{array}{l}\text { Photosynthetic } \\
\text { rate }(\mathrm{A}) \\
\mu \mathrm{mol} /\left(\mathrm{m}^{2} . \mathrm{s}\right)\end{array}$ & $\begin{array}{l}\text { Transpiration rate (E) } \\
\quad \mathrm{mmol} \mathrm{H}_{2} \mathrm{O} /\left(\mathrm{m}^{2} . \mathbf{s}\right)\end{array}$ & $\begin{array}{l}\text { Stomatal conductivity (Gs) } \\
\mu \mathrm{mol} \mathrm{CO} \mathrm{CO}_{2} / \mathrm{mol}-\end{array}$ & $\begin{array}{l}\text { Leaf temperature (Tci) } \\
\left({ }^{\circ} \mathrm{C}\right)\end{array}$ \\
\hline \multirow[t]{2}{*}{ G. schomburgkii } & Soil & $7.84 \pm 0.66$ & $2.96 \pm 0.27$ & $0.13 \pm 0.01$ & $36.71 \pm 1.23$ \\
\hline & Hydroponic & $8.38 \pm 1.20$ & $3.08 \pm 0.37$ & $0.22 \pm 0.0^{* *}$ & $33.70 \pm 1.47$ \\
\hline \multirow[t]{2}{*}{ G. marantina } & Soil & $5.57 \pm 0.74$ & $1.96 \pm 0.26$ & $0.09 \pm 0.01$ & $34.24 \pm 1.08$ \\
\hline & Hydroponic & $6.12 \pm 0.04$ & $2.11 \pm 0.10$ & $0.11 \pm 0.01^{* *}$ & $33.87 \pm 1.58$ \\
\hline
\end{tabular}

${ }^{* *} \mathrm{p}<0.01$ statistically significant difference from soil condition 

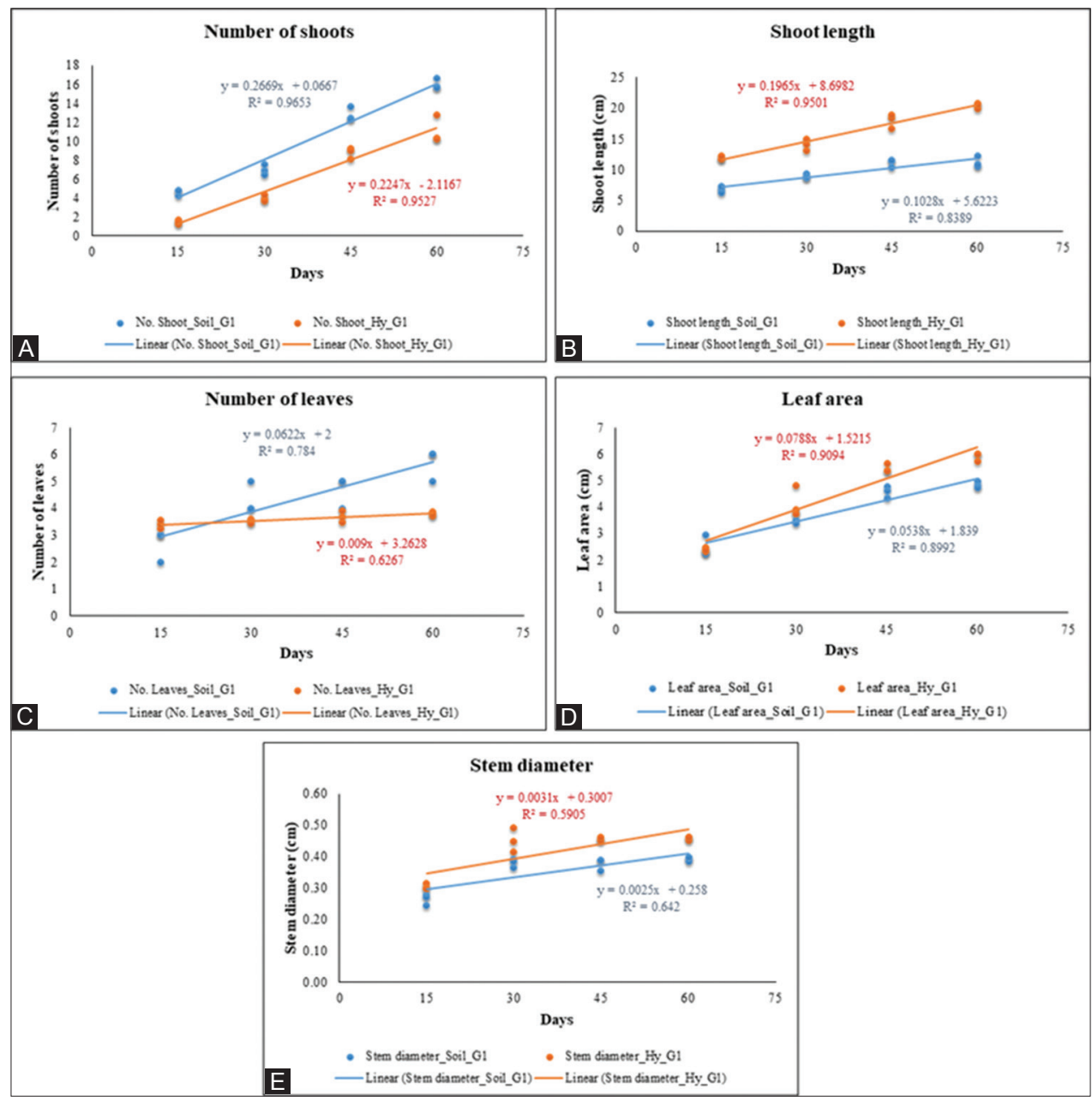

Fig 2. The relationship between G. schomburgkii grown in soil and hydroponic conditions; (A) days and number of shoots, (B) days and shoot length, (C) days and number of leaves, (D) days and leaf area and (E) days and stem diameter. Linear regression fits and associated $R^{2}$ values are displayed in each figure.

Table 3: Reproductive growth indices of G. schomburgkii and G. marantina at 60 DAT.

\begin{tabular}{|c|c|c|c|}
\hline \multirow[t]{2}{*}{ Treatments } & \multicolumn{3}{|c|}{ Parameters } \\
\hline & No. of inflorescence \pm SE & Inflorescence length $\pm S E$ & No. of flowers $\pm S E$ \\
\hline T1 & $4.633 \pm 0.07^{\mathrm{b}}$ & $4.89 \pm 0.05^{b}$ & $4.05 \pm 0.11^{\mathrm{bc}}$ \\
\hline T2 & $3.43 \pm 0.05^{c}$ & $4.47 \pm 0.13^{b}$ & $3.79 \pm 0.14^{c}$ \\
\hline T3 & $5.90 \pm 0.17^{\mathrm{a}}$ & $5.41 \pm 0.27^{\mathrm{a}}$ & $4.74 \pm 0.13^{\mathrm{a}}$ \\
\hline T4 & $3.00 \pm 0.20^{c}$ & $3.90 \pm 0.02^{c}$ & $4.22 \pm 0.06^{b}$ \\
\hline F-test & ** & ** & ** \\
\hline
\end{tabular}

after transplanting from in vitro culture into hydroponic conditions, plantlets of G. schomburgkii and G. marantina can adapt to the ex vitro conditions and root structure supported the hypothesis that both species can be successfully reared in hydroponic culture. These results were similar to other authors who successfully produced several ornamental plants to increase productivity by this method such as: Anthurium andreanum (Dufour and Guérin, 2005), Althaea rosea, Calendula officinalis and Impatiens balsamina (Liu et al., 2008), Gerbera (Khalaj et al., 2011; Karras et al., 2007),
Gladiolus (Milandri et al., 2008; Nosir, 2011) and Iris (Chang et al., 2010).

Two weeks after transplanting into soil, plantlets of $G$. schomburgkii and $G$. marantina well adapted to the condition with new leaves and after two months, all plantlets survived. Modern growing media provide aeration and water absorption, oxygen and other nutrients that affect growth and development (Verdonck et al., 1982; El-Sayed et al., 2015). Different materials may impact the plants 

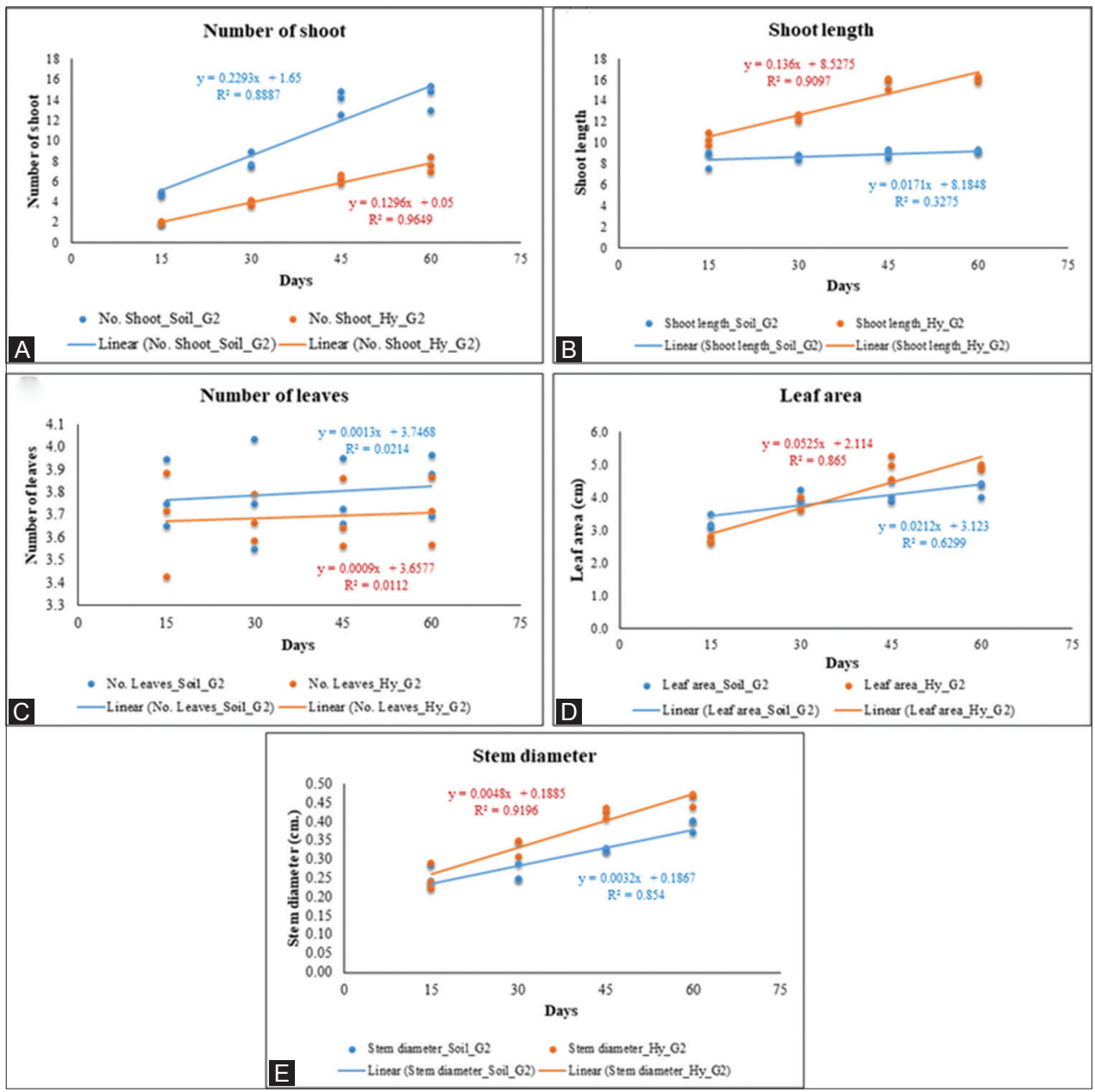

Fig 3. The relationship between G. marantina grown in soil and hydroponic conditions; (A.) days and number of shoots, (B.) days and shoot length, (C.) days and number of leaves, (D.) days and leaf area and (E.) days and stem diameter. Linear regression fits and associated $R^{2}$ values are displayed in each figure.
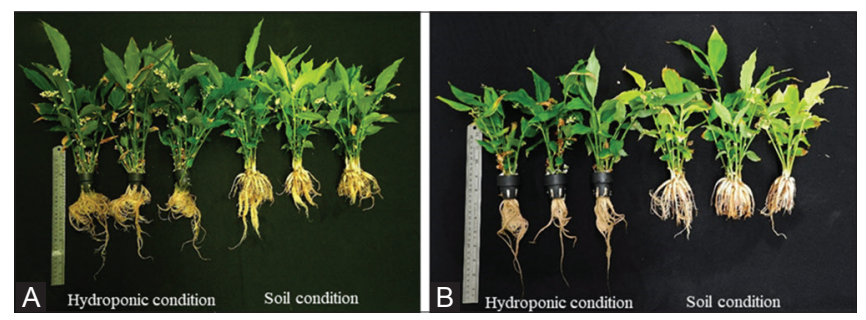

Fig 4. Characteristics of roots; (A) Roots of G. schomburgkii grown in hydroponic and soil conditions after 60 DAT and (B) Roots of G. marantina grown in hydroponic and soil conditions after 60 DAT.

directly. Therefore, suitable material selection is vital in determining productivity increments (Olympious, 1992). After transplantation, plantlets of G. schomburgkii and G. marantina can adapt to the ex vitro conditions as well as adapting to soil conditions. These results were similar to observations from other authors. For example, Chanchula (2012) studied another species of genus Globba (Globba williamsiana) and found that the highest $94.44 \%$ survival rate was in sand: burned rice husk: peat moss (1:1:1 by volume), while in this study both species had 100\% survival rate.
Both G. schomburgkii and G. marantina were reported to have annual inflorescences between June and September (Saensouk et al., 2017). However, this study showed inflorescences of both species from October to November, indicating that they can bloom out of season. Therefore, extending the inflorescence period from nature may have been induced with the hydroponics or continuous watering. Thus hydroponic technique has an advantage to increase flower production as reported in Asiatic hybrid lily cv. "Blackout" (Asker, 2015), gladiolus (Norsir, 2011) and Anthurium andreanum (Dufour et al., 2005).

\section{Physiological responses in hydroponic and soil conditions}

There were no significant differences in the photosynthetic rate, the transpiration rate and leaf temperature, however stomatal conductance significantly differed between the soil and hydroponic cultures. These results were similar to Zhang et al. (2013) who reported that the net photosynthetic rate, the transpiration rate of lotus were not significantly different between hydroponic and soil culture. From this result, 
hydroponic plants accumulate $\mathrm{CO}_{2}$ with higher stomatal conductance and are well adapted to increase photosynthetic rate leading to higher growth. Hydroponic culturing increases leaf area index so as to improve the photosynthetic rate (Qiuying et al., 2005; Gajewska et al., 2006; He and Tan, 2011), which was consistent with that of stomatal conductivity and these results indicate that there was a difference between the two conditions in term of leaf physiological index. Hence, the result showed that G. schomburgkii and G. marantina are capable of adapting to a water-culture environment.

\section{CONCLUSION}

The two Globba species can adapt well to the conditions under greenhouse and plantlets showed 100\% survival rate after transplanting. Globba plants grown in hydroponic system had more leaf area, greater shoot lengths and stem diameter in addition to earlier inflorescences and more flowers than those of soil conditions. Soil conditions provided the most shoots and displayed tuberous roots in response to low water level in soil compared with hydroponics where plant roots were in constant contact with the water. Thus, Globba production in hydroponic system can be an alternative way for production of Globba into cut flower or pot plants in the future. Moreover, at present these system successful commercial and it's can also control several factors such as mineral nutrient composition, $\mathrm{pH}$ and $\mathrm{EC}$ of nutrient solution, etc. However, hydroponics would be more fruitful for ginger family plants providing realistic growth conditions, due to the long root systems. In conclusion, the results from this study will provide a useful information for gardener to develop a sustained method for cultivation of agricultural crops and this can solve the problem of an unsuitable planting area.

\section{ACKNOWLEDGEMENTS}

The funding for this project was supported by Suranaree University of Technology-National Research fund. The authors thank Suwan Sukjarone and Chonlathon Pokaew for technical help. The authors also thank Dr. Colin T. Strine, an anonymous reviewer, for improving the manuscript.

\section{Conflict of interests}

The authors declare that there is no conflict of interest regarding the publication of this paper.

\section{Author contributions}

P.P. performed the experiments, analyzed the results and prepared the manuscript. T.M. designed the research. P.S. revised the manuscript. N.M. designed the research, analyzed the results and revised the manuscript.

\section{REFERENCES}

Asaduzzaman, K. Yutaro, F. Mondal, B. Takuya, M. Hitoshi, A. Fumihiko and A. Toshiki. 2013. Growing carrots hydroponically using perlite substrates. Sci. Hort. 159: 113-121.

Asao T., Asaduzzaman, F. Mondal, T. Mayumi, A. Fumihiko, U. Makoto, K. Mikiko, Y. Shozo and B. Takuya. 2013. Impact of reduced potassium nitrate concentrations in nutrient solution on the growth, yield and fruit quality of melon in hydroponics. Sci. Hort. 164: 221-231.

Asker, H.M. 2015. Hydroponic technology for lily flowers and bulbs production using rainwater and some common nutrient solutions. Afr. J. Biotechnol. 14(29): 2307-2313.

Caruso, G., V. Gerardo, M. Giuseppe and C. Stefano. 2011. Effects of cultural cycles and nutrient solutions on plant growth, yield and fruit quality of alpine strawberry (Fragaria vesca L.) grown in hydroponics. Sci. Hort. 129(3): 479-485.

Chanchula, N. 2012. Embryo culture and induced mutation in vitro culture on Globba spp. M.Sc. Thesis, Kasetsart University.

Chang, J., L. Dong, C. Haiqin, S. X. Chang, W. Xiaoyue, H. Chengcai and G. Ying. 2010. $\mathrm{NO}_{3}{ }^{-} / \mathrm{NH}_{4}{ }^{+}$ratios affect the growth and $\mathrm{N}$ removal ability of Acorus calamus and Iris pseudacorus in a hydroponic system. Aquat. Bot. 93(4): 216-220.

Damna, N., W. Saikaew and A. Tira-amphon. 2017. Effect of fertilizer type and light filter level to yield and quality of Wolffia arrhizal (L.) Wimm. Songklanakarin J. PI. Sci. 4(3):60-64.

Dufour, L. and V. Guérin. 2005. Nutrient solution effects on the development and yield of Anthurium andreanum Lind. in tropical soilless conditions. Sci. Hort. 105(2): 269-282.

El-Sayed, S. F., H. A. Hassan and S. O. Mahmoud. 2015. Effect of some soilless culture techniques on sweet pepper growth, production, leaves chemical contents and water consumption under greenhouse conditions. Middle East J. 4(4): 682-691.

Gajewska, E., M. Sklodowska, M. Slaba and J. Mazur. 2006. Effect of nickel on antioxidative enzyme activities, proline and chlorophyll contents in wheat shoots. Biol. Plant. 50(4): 653-659.

$\mathrm{He}, \mathrm{A}$. and X. Tan. 2011. Comparative analysis of different leaf age of saxifrage based on photosynthetic characters and leaf structure. Chinese. Agric. Sci. Bulletin. 27(16): 122-125.

Karras, G., S. Dimitrios, P. George, P. Philipos and A. Triantafyllos. 2007. Fate of cyromazine applied in nutrient solution to a gerbera (Gerbera jamesonii) crop grown in a closed hydroponic system. Crop Prot. 26(5): 721-728.

Khalaj, M. A., M. Amiri and S. S. Sindhu. 2011. Response of different growing media on the growth and yield of gerbera in hydroponic open system. Indian J. Hortic. 68(4): 583-586.

Libia, I., T. Trejo, C. Fernando and M. Gomez. 2012. Nutrient solution for hydroponic systems, book Hydroponics - a standard methodology for plant biological researches by Toshiki Asao, Published by In Tech com.

Liu, J., Z. Qi-xing, S. Ting, Ma. Lena and W. Song. 2008. Growth responses of three ornamental plants to $\mathrm{Cd}$ and $\mathrm{Cd}-\mathrm{Pb}$ stress and their metal accumulation characteristics. J. Hazard. Mater. 151(1): 261-267.

Milandri, S. G., C.P. Laubscher and P. A. Ndakidemi. 2008. Hydroponic culture of Gladiolus tristis: Application of paclobutrazol for flowering and height control. Afr. J. Biotechnol. 7(3).

Monnet, F., V. Nathalie, H. Adnane, V. Philippe, C. Alain and S. Huguette. 2002. Treatment of domestic wastewater using the nutrient film technique (NFT) to produce horticultural roses. Water. Res. 36: 3489-3496. 
Murashige, T. and F. Skoog. 1962. A revised medium for rapid growth and bioassays with tobacco tissue cultures. Physiol. Plant. 15: 473-497.

Nosir, W. 2011. Efficiency of using commercial fertilizers for Gladiolus growth in nutrient film technique. J. Plant Nutr. 34(7): 963-969.

Olympious, C.M. 1992. Soilless media under protected cultivation rockwool, peat, perlite and other substrates. Acta Hortic. 401: 443-451.

Pimmuen, P., S. Piyaporn and S. Surapon. 2014. In vitro propagation of Globba marantina L. KKU Res. J. 19: 596-605.

Qiuying, Z., F. Li and M. Liu. 2005. Changing laws of chlorophyll content and photosynthetic rate in winter wheat leaves. Chinese J. Eco-Agriculture. 13(3): 95-98.

Saensouk, S., S. Piyaporn and C. Nachay. 2017. Diversity and traditional uses of Zingiberaceae in Nong Khai Province, Thailand. KKU Sci. J. 45(3): 574-594.
Selma, M. V., M. C. Luna, A. M. Sánchez, J. A. Tudela, B. David, B. Carlos and M. I. Gil. 2012. Sensory quality, bioactive constituents and microbiological quality of green and red fresh-cut lettuces (Lactuca sativa L.) are influenced by soil and soilless agricultural production systems. Postharvest. Biol. Tec. 63: 16-24.

Syros, T., Y. Traianos, O. Michael and E. Athanasios. 2004. Photosynthetic response and peroxidases in relation to water and nutrient deficiency in gerbera. Environ. Exp. Bot. 52(1): 23-31.

Toshiki, A. 2012. Hydroponics - a standard methodology for plant biological researches. Published by InTech com.

Verdonck, O., D. De Vleeschauwer and M. De Boodt. 1982. The influence of the substrate to plant growth. Acta Hortic. 126: 251-258.

Zhang, Y., L. Wenling, M. Weifang and K. Dezheng. 2013. A Comparative study on the leaf characteristics and root vigor of bowl lotus under hydroponics and soil culture. Agric. Sci. Technol. 14(9): 1267-1270. 